\title{
HOE CANTZ'LAAR GOUVERNEUR VAN CURAÇAO WERD
}

\author{
DOOR
}

\author{
MR. B. DE GAAY FORTMAN
}

In de geheel afzonderlijke kolonie St. Eustatius, Saba en St. Martin (Nederlandsch gedeelte) van 1816-1828 was het laatstgenoemde eiland, met Saba daaronder begrepen, een żelfstandig onderdeel, zooals Bordewijk aan de hand van het Reglement op het beleid der Regering, het justitiewezen, den Handel en Scheepvaart op die drie eilanden, bij K.B. van 14 September 1815 vastgesteld, aantoont ${ }^{1}$ ). Onder meer werd de Commandeur van St. Martin, die onder de orders van den Gouverneur van St. Eustatius zou staan, door den Koning benoemd.

Aan de groote belangrijkheid van dit bezit kan dit niet toegeschreven worden, en ook misplaatste grootheidswaan zal wel niet deze regeling bepaald hebben. Immers Falck, die het weten kon, en van 1818-1824 zelf Minister van Onderwijs, Nationale Nijverheid en Koloniën was, schreef in 1822: „Van weinig meer belang dan de kust van Guinea waren de eilanden St. Eustatius en St. Martin. Bij gebrek aan voordeeliger gebruik deed ik ze strekken tot een oefenschool voor Koloniale Gezaghebbers. Cantz'laar heb ik achtervolgens van daar naar Curaçao en A. de Veer naar Suriname doen overgaan." ${ }^{2}$ )

Het treft wel, dat deze betrekkingen destijds zoo in aanzien stonden, dat men voor Gouverneur der drie bovenwindsche eilanden een man als De Veer, generaalmajoor in rang, gewezen Commandeur-Generaal ter kuste

$\left.{ }^{1}\right)$ Ontstaan en ontwikkeling van het Staatsrecht van Curacao, bladz. 39.

$\left.{ }^{2}\right)$ Gedenkschriften, meegedeeld in dit tijdschrift 1923, bladz. 444 en 445 . 
van Guinea, bereid kon vinden, en onder hem als Commandeur van St. Martin Cantz'laar.

Paulus Roelof Cantz'laar was den 22sten November 1771 te Amsterdam geboren. In 1790 in militairen zeedienst getreden, werd hij vijf jaren later tengevolge der omwenteling ontslagen. In 1799 trad hij opnieuw in dienst, en werd in 1813 in een zeegevecht tegen de Engelschen gevangen genomen en naar Engeland opgebracht, waar hij tot de herstelling van het Oranjehuis bleef. Even was hij toen nog als kapitein ter zee commandant van het door hem in 1814 opgerichte bataillon mariniers, om reeds in het volgend jaar tot Kommandeur van St. Martin en Saba benoemd te worden, waar hij 6 Januari 1816 het bestuur van de Engelschen overnam.

Het volgende stuk, ingeschreven in het doorloopende gouvernementsjournaal, en door hem geteekend, verhaalt zijn wedervaren na zijne terugroeping naar het Moederland.

\section{INLEIDING VOOR HET JOURNAAL}

Op den 5en Januarij dezes Jaars 1820, tijdens ik mij nog te St. Martin bevond in kwaliteit als Kommandant over dat Eiland en het Eiland Saba, werd mij door Zijne Excellentie den Heer A. de Veer, als Gouverneur van St. Eustatius en onderhoorige Eilanden, die zich tot dat einde naar St. Martin had begeven, ter hand gesteld eene depêche van Zijne Excellentie den Minister voor het Publieke onderwijs, de Nationale Nijverheid en de Kolonien, dd. 23 October 1918 no. 6/11, inhoudende, dat ik met voorkennis van Zijne Majesteit gemagtigd en aangeschreven werd tot het doen van eene keer naar Nederland, met verdere aanschrijving dat ik, zoodra de Heer Gouverneur De Veer de noodige schikkingen zoude hebben gemaakt omtrent de waarneming ad-interim van het bestuur op St. Martin, mij hetzij regtstreeks, hetzij met de Paketboot over Engeland naar Nederland zoude begeven en na behoudene aankomst bij Zijne Excellentie den Minister voormeld zoude vervoegen, daarbij werd nog bepaald, dat de kosten dier reize mij van 's Rijkswege zoude worden vergoed en gedurende mijne afwezigheid, het genot van mijn traktement zoude doorloopen, - al dadelijk den volgenden dag tusschen gezegde Heer 
Gouverneur en mij de noodige schikkingen gemaakt zijnde omtrent de waarneming ad interim van het bestuur op St. Martin, is dien ten gevolge het bestuur ad interim van opgenoemde Kolonien op den 5en Februari van dit jaar, overgegaan in handen van den Heer D. J. van Ramondt, Fiscaal aldaar.

Het toenmaals plaatshebbende ongunstig weder was oorzaak dat ik tot aan den 8sten heb moeten vertoeven, alvorens mij naar het Eiland St. Thomas te kunnen begeven, alwaar ik inmiddels mijne passagie had doen engageren aan boord eener Zweedsche Brik genaamd de Twee gebroeders en gevoerd bij Kapitein Simonsson- den 9den aldaar aangekomen zijnde en gebruik gemaakt hebbende van het vriendelijk aanbod van den toenmaligen Kommandant adîntm., aldaar den Heer Von Schollen, welke mij met een salut en verdere Militaire honneurs aan mijnen rang toekomende had doen recipieeren, heb ik met mijne bijhebbende famillie, mijn intrek ten zijnen of Gouvernements huize genomen gehad, tot aan den dag van mijn vertrek van dat Eiland, hetwelk op den 13en heeft plaats gehad, wanneer ik bij het van land gaan wederom met een Salut van dertien Schoten ben begroet geworden.

Den 12den April was de gelukkige dag waarop wij na eene reize van circa twee maanden, gedurende welke wij veel slegt weer en stormen hadden ondervonden, in een slegt bezeild vaartuig en niet genoegzaam van de benoodigde zeilen voorzien, die nog bovendien grootendeels in eene genoegzaam onbruikbare staat waren, in het vaderland mogten aankomen en aan den Helder voet aan Land zetten - en zijn wij nog in den avond van dienzelve dag in Amsterdam aangekomen, van waar ik mij daags daaraan en dus den 13den naar 's Gravenhage heb begeven, met oogmerk en naar luid der hiervorengemelde aanschrijving mij bij Zijne Excellentie den Heer Minister te vervoegen, waarin ik te leur werd gesteld door deszelfs afwezigheid, als zijnde reeds eenigen tijd geleden naar Weenen vertrokken, werwaarts dezelve met eene zending vanwege Zijne Majesteit was belast geworden, waarom ik Zijne Excellentie, bij missive, van mijn behouden aankomst in Nederland heb kennis gegeven. - Evenwel verlangende dat Zijne Majesteit kennis zoude dragen van mijne aankomst in het vaderland en tevens om in de gelegenheid gesteld te wezen mijne opwachting te mogen maken bij Hoogstdeszelfs persoon heb ik mij den volgenden dag daarover in geschrift geadresseerd aan $\mathrm{Zijne}$ Excellentie den Opperkamerheer van Zijne Majesteit, waarop rescriptie heb bekomen, dat Zijne Majesteit mij op den volgenden 
donderdag (den 20en April) zoude ontvangen. - Dan op daartoe bekomen invitatie, genoot ik de Eer den 18en bevorens aan Zijner Majesteits tafel ter middagmaal toegelaten te wezen, waardoor ik in de gelegenheid gesteld werd aan Zijne Majesteit den Koning, aan Hare Majesteit de Koninging en aan Zijne Koninglijke Hoogheid Prins Frederik der Nederlanden mij te presenteren, over het minzaam accueil van alle welke hooge vorstelijke personen ik alle reden had mij gelukkig te achten.

Mij vervolgens op den 20sten ter audientie bij Zijne Majesteit vervoegd hebbende, behaagde het Hoogstdenzelven mij alleenlijk, in zoo ver wegens het oogmerk van mijn opontbod naar Nederland inteligten, dat ik de betuiging ontving van hoogstdeszelfs tevredenheid over mijn gehouden gedrag te St. Martin en dat ik waarschijnlijk over mijne volgende bestemming zoude te vreden wezen, dog dat de beslissing daarvan moest uitgesteld worden tot aan de terugkomst van Zijne Excellentie den Minister voor het Publieke onderwijs, de Nationale Nijverheid en de Kolonien, en welken afzijn, mijn verblijf in het vaderland nog eenigen tijd zoude verlengen. - nog dienzelven dag werd ik ter audientie toegelaten bij Zijne Koninklijke Hoogheid Prins Frederik der Nederlanden en den 22e daaraanvolgende bij Zijne Koninglijke Hoogheid den Prins van Oranje.

Inmiddels zijn op verzoek van den Heer De Munnick ${ }^{1}$ ), kommissaris bij het Ministerie, bij welken Heer ik mij bij afwezigheid des Ministers had vervoegd door mij gesteld en aan het Ministerie ingediend geworden twee memorien, als een wegens de bezuiniging die in de administratie der kolonie St. Martin zoude kunnen worden daargesteld, gedateerd 17 April 1820, en eene wegens de wijze van schadeloosstelling aan de Ingezetenen der Kolonie St. Martin, ten gevolge der orkaan tusschen den 21 en 22 September 1819, aldaar gewoed hebbende, gedateerd 18 April 1820 , - waarna ik de residentie heb verlaten om mij met mijne partikuliere zaken en belangens bezig te houden. -

Den 6en Juni, Zijne Excellentie na deszelfs zending in 's Gravenhage terug gekomen zijnde, begaf ik mij den 8ste daaraanvolgende derwaarts en had de eer den 10den op eene partikuliere audientie ten huize des Ministers te worden ontvangen, waar ook ik de voldoening genoot de betuiging van tevredenheid over mijn gedragen handelingen in het aan mij toevertrouwd geweest bestuur over de kolonie St. Martin te ontvangen; met de voor mij

1) Over hem: Falck, t.a.p. in „de W. I. G.” 1923 bladz. 444. 
vleijende verzekering dat ik door Zijne Excellentie aan Zijne Majesteit tot het Gouvernement van Curaçao, hetwelk door het overlijden van Zijne Excellentie den vice Admiraal Kikkert was opengevallen, al dadelijk zoude worden voorgedragen, zooals het dan ook Zijne Majesteit goedgunstiglijk heeft behaagd mij, bij hoogstdeszelfs besluit van 25 Juni 1820 no. 69, honorabel te ontslaan als kommandeur der Eilanden St. Martin en Saba en aan te stellen tot Gouverneur van het Eiland Curaçao en onderhoorige Eilanden Bonaire en Aruba, en tevens bij besluit van 2 Julij 1820 no. 20, mij kennelijk geworden bij aanschrijving van Zijne Excellentie den Minister voor de Marine, dd. 5e July deszelven Jaars no. 20, mij toe te staan den rang van Schout bij nacht.

Daarna mij op onderscheidene tijden naar 's -Gravenhage begeven, ten einde met Zijne Excellentie den Minister te aboucheeren, zoo wegens de belangens van het Eiland Curaçao, als weegens de middelen ter bespoediging van mijn vertrek naar de plaats mijner bestemming, omtrent welk laatste point bepaald zijnde dat ik de overtogt naar Curaçao zoude doen in het Brikschip de Maria en Jacoba gevoerd bij kapitein I. I. Bart zijn dienaangaande door mij de noodige schikkingen gemaakt en overeenkomsten getroffen met de Reeders van dat vaartuig de Heeren Buis, de Bordes en Jordan. - waarna ik mij naar het Loo, alwaar Zijne Majesteit de Koning zich toenmaals bevond, heb begeven en bij gelegenheid eener publieke audientie op den 28 Augustus verleend, Zijne Majesteit mijnen dank heb mogen betuigen voor Hoogstdeszelfs genomen gunstige dispositien te mijwaards en na het middagmaal bij hetwelke ik de eer had andermaal genoodigd te wezen; van Hoogstdenzelven, Hare Majesteit de Koningin en Z. K. H. Prins Fredrik der Nederlanden afscheid te nemen, na Hoogstdeszelfs laatste bevelen te hebben gevraagd.

Wijders informatie bekomen hebbende dat het Brikschip Maria en Jacoba tegen het laatst der maand September of het begin van October in gereedheid zoude zijn zee te kiezen, heb ik op den 19den September voor de laatste maal mij vervoegd bij Zijne Excellentie den Minister ten einde mijne verschuldigde pligtsplegingen af te leggen en deszelfs nadere instructien te ontvangen, vooral ook betrekkelijk den nog door mij afteleggen Eed als Gouverneur van Curaçao en onderhoorige Eilanden, waaromtrend door Zijne Majesteit werd bepaald dat die door mij schriftelijk zoude worden ingeleverd, zoo als dan ook daaraan en wel op den $22 \mathrm{e}$ is voldaan en bij missive van dezelve dagteekening aan Zijne Excellentie den Minister is ingezonden geworden. 
Eindelijk mij berigt zijnde dat meergemelde Brikschip van voor de stad Amsterdam naar de Reede van Texel was onderzeil gegaan, heb ik mij op den 2den October met mijne Echtgenoote en domestieken van eerstgemelde plaats naar de Helder begeven en zijn wij, na dat op den 4den de Brik aldaar ter Reede was aangekomen, den 5den daaraanvolgende geembarkeerd en op den middag van dien dag met een gunstige wind naar zee gezeild ; geene merkwaardigheden hebben onze overtogt vergezeld, voortdurende gunstige winden voerden ons gelukkig en voorspoedig naar de plaats onzer bestemming alwaar wij den 12en November door Gods goedheid behouden aangekomen en aan Land gestapt zijn.

„Gouverneur-Generaal" was van 1816-1820 de titel geweest van des Konings vertegenwoordiger, Cantz'laar zou niet meer dan Gouverneur zijn, symbool van de reorganisatieplannen en van de bezuinigingsmaatregelen in het bijzonder, waarmee hij uit Holland was gekomen. Hij vond het nuttig tot de helft der maand, een geschikt tijdstip om de boeken af te sluiten, te wachten met de aanvaarding van het bewind.

Cantz'laar moet eerst niet anders gedacht hebben dan dat hij van Mr. P. B. van Starckenborgh, den raad-fiskaal, sinds 19 Dec. 1819 opvolger ad interim van den Gouverneur-Generaal Vice-admiraal Albert Kikkert, het bestuur zou overnemen, maar na 6 maanden, 20 Juni 1820 had ook deze het tijdelijke met het eeuwige verwisseld, en Mr. I. J. Elsevier, als lid van den raad van justitie in 1816 in de kolonie gekomen, in hetzelfde jaar met de waarneming van de voorzitting van dit college belast, en na Kikkerts dood met die van het ambt van raadfiskaal, had als zoodanig Van Starckenborghs taak overgenomen.

Mr. Elsevier is dan ook de voorzitter van de gecombineerde vergadering der raden van politie en van civiele en crimineele justitie, waarin op 16 November 1820 Cantz'laars installatie plaats vond. Met hem waren aanwezig: Mr. Daniel Serrurier, raad-fiskaal ad interim, C. L. van Uytrecht, raad-contrarolleur-generaal der financiën ad interim, en de raadsleden B. A. Cancryn, Theods. Jutting en 
Charles August baron de Larrey ${ }^{1}$ ); Mr. W. W. Duyckinck waarnemend voorzitter van den raad van justitie, Mr. $\mathrm{H}$. R. Hayunga, Frans Royer, W. A. van Spengler, raden van justitie, en G. Striddels, raad-ordinaris ad interim. Secretaris van den raad van politie was W. Prince.

Cantz'laar bedankt Mr. Elsevier voor zijn interimaat, en doet voorloopig meedeeling van een ,,gunstige en weldadige dispositie” van de koning ,zoo met betrekking tot eene aannerkelijke bezuiniging in de administratiekosten als met betrekking tot eene aanzienlijke vermindering der belastingen over het aanstaande jaar 1821." De reorganisatie der administratie zou denzelfden dag ingaan. Hij deed een beroep op den raad van politie, om met hem ,de meest doelmatige maatregelen te nemen om den vervallen staat van 's Rijks financiën alhier en die der sluimerende Commercie zooveel mogelijk te verbeteren en op te beuren".

Het was inderdaad een ,gepaste aanspraak", zooals men dit destijds noemde, waarmee de voorzitter der vergadering den nieuwen gouverneur het welkom toeriep. „De Raad van Policie” ...., aldus Mr. Elsevier, „vond in de keuze en despeche van Uwer Excellenties persoon tot Gouverneur dezes en onderhoorige Eilanden, zoo mede in hetgeen uw Excellentie denzelven voorloopig omtrent het nieuw beheer, heeft gelieven te communiceeren den sterksten en zekersten waarborg van Zijne Majesteits welwillendheid en vaderlijke gevoelens voor, en deelneeming in het lot, dezer zoo zeer verarmde Colonie, 't welk, zoo het immer voor verbetering vatbaar zy, en de volkplanting zelve tot den vorigen bloei is weder te brengen, zulks aan niemand betere zorge en directie konde worden toebetrouwd dan aan die van uwe Excellentie als zoo overbekend met de Coloniale belangens". -

Bij De Veer rekende Falck „op kloekmoedigheid en ook op voortvarendheid”, bij Cantz'laar „daarenboven

1) Er was eene vacature omdat Van Uytrechts plaats bij zijne benoeming tot contrarolleur generaal der financiën niet vermeld was. 


\section{HOE CANTZ'LAAR GOUVERNEUR VAN CURAÇAO WERD}

op administratief beleid en een doorstaanden geest van spaarzaamheid en orde."

Simons en Brusse, die in dit stuk hunner Curaçaosche geschiedbeschrijving slechts één van beiden of geen van beiden oorspronkelijk zijn, zijn maar slecht te spreken over Cantz'laars bestuur. Ik hoop binnen niet te langen tijd hierover het licht der officieele bronnen te doen opgaan. Zeker is, dat in het Moederland zijn beleid waardeering vond. Toen in 1828 alle Nederlandsche West-Indische bezittingen onder één Gouverneur-generaal vereenigd werden moest De Veer, Cantz'laars chef in het gouvernement van St. Eustatius c.a., zijn zetel op het plein te Paramaribo voor hem inruimen, maar overleefde hem. Cantz'laar overleed te Paramaribo 15 Dec. 1831. 